\title{
Quantitative Differential Expression of Alpha and Beta Ryanodine Receptor Genes in PSE (Pale, Soft, Exudative) Meat from Two Chicken Lines: Broiler and Layer
}

\author{
Sandra Helena Inoue Oda ${ }^{1}$, Alexandre Lima Nepomuceno ${ }^{2}$, Mônica Corrêa Ledur ${ }^{3}$, Maria \\ Cristina Neves de Oliveira ${ }^{2}$, Silvana Regina Rockenbach Marin ${ }^{2}$, Elza Iouko Ida ${ }^{1}$ and \\ Massami Shimokomaki ${ }^{*}$ \\ ${ }^{I}$ Departamento de Ciências e Tecnologia de Alimentos; Centro de Ciências Agrárias; Universidade Estadual de \\ Londrina, C. P.: 600; 86051-970; Londrina - PR - Brasil. ${ }^{2}$ Centro de Pesquisa Embrapa Soja; 86001-970; Londrina \\ - PR - Brasil. ${ }^{3}$ Centro de Pesquisa Embrapa Suínos e Aves; 89700-000; Concordia - SC - Brasil
}

\begin{abstract}
Total RNA isolated from Pectoralis major muscle from PSE $\left(L^{*}{ }_{24 h}>53.0, p H<5.8\right)$ and non-PSE $(44 \leq L * 24 h \geq 53)$ meats of two phenotypically distinct chicken lines, broiler and layer, was used to investigate the $\alpha$-ryr and $\beta$-ryr gene expression by real-time RT-PCR approach. Mean relative quantification (RQ) values were lower $(p<0.05)$ for $\beta$-ryr in PSE chickens from both lines when compared to non-PSE chickens, while there was no difference $(p>0.05)$ in $\alpha$-ryr gene expression regardless of line studied. The $\beta$-ryr $R Q$ results suggested that in PSE samples an alteration might occur in the regular ratio (1:1) of $\alpha-R y R / \beta-R y R$ normally found in avian muscles. These results provided the first evidence of PSE meat occurrence as a result of the differential expression of ryanodine receptor genes which might lead to an increased in $\mathrm{Ca}^{2+}$ availability at the cell milieu.
\end{abstract}

Key words: malignant hyperthermia, poultry, gene expression, real time PCR

\section{INTRODUCTION}

The increased consumption of avian fresh meat and its products in recent years has led to the rise of raw material quality problems, associated with toughness, low cohesiveness, color and water holding capacity (Dransfield and Sosnicki, 1999). These problems are a consequence of breeding programs established to develop the birds with a rapid growth rate and high breast yield, giving rise to the appearance of the so-called, modern chicken. Genetic selection has also been conducted leading to changes in some other characteristics, such as an increase in the rapid contraction muscle fibers, limited vessel networks, accelerated post mortem glycolysis and a higher susceptibility to stress factors (Le Bihan-Duval et al., 1999).

Poultry PSE (Pale, Soft, Exudative) meat represents an economical problem for the meat industry affecting the development of competitiveness for meat products because of impairment of the meat functional properties. While much is known about PSE in pigs, the fundamental biochemical knowledge of this

\footnotetext{
*Author for correspondence: mshimo@uel.br
} 
syndrome in poultry still remains to be confirmed despite its intensive investigation. Recent reports have shown that PSE in poultry is related to animal nutrition (Olivo et al., 2001), meat phospholipase $\mathrm{A}_{2}$ activity (Soares et al., 2003) and pre-slaughtering management (Guarnieri et al., 2004). However, impairment in calcium efflux from the sarcoplasmic reticulum (SR) to the sarcoplasm by calcium channel proteins is linked to this meat quality problem (Werner et al., 2005). In swine, a point mutation in the DNA sequence that coded the ryanodine receptor 1 (RyR1) was identified (Fujii et al., 1991). This mutation leads to the pork stress syndrome, which is equivalent to human malignant hyperthermia (McLennan and Phillips, 1992, Jurkat-Rott et al., 2000), a membrane linked disease. The participation of RyR has not yet been fully related to the occurrence of poultry PSE meat although several authors have reported genetic similarities between different species (Owens et al., 2000; Lara et al., 2003; Strasburg and Chiang, 2003). Two RyRs are co-expressed at the same ratio in avian, amphibian and piscine fast twitch skeletal muscles. These two isoforms, homologous to RyR1 and RyR3, were named $\alpha-R y R$ and $\beta$-RyR, respectively. There are differences in the excitation-contraction (EC) coupling mechanisms between mammals and avians. In avian muscles, tubules $\mathrm{T}$ depolarization induces the structural modification of dihydropyridine receptor (DHPR), which is physically connected to the $\alpha$-RyR and finally resulting in the $\mathrm{Ca}^{2+}$ release by the calcium channel. The local increase in $\mathrm{Ca}^{2+}$ ions concentration results in the activation of the channel and in the $\mathrm{Ca}^{2+}$ efflux by $\beta$-RYRs (Strasburg and Chiang, 2003). On the other hand, in mammals, $\mathrm{Ca}^{2+}$ release to the cytosol is controlled only by RyR1 (Percival et al., 1994).

The expression of genes is mainly regulated by regulatory sequences (promoters, enhancers) located up stream from the gene start codon. Polymorphism in these sequences and their interaction with regulatory factors and RNA polymerases can determine the initiation and the efficiency of mRNA transcription (Lin and Barbosa, 2002). Thus, the comprehension of the factors and processes that induce and regulate the expression of ryanodine receptors expression and their interaction with other factors to lead $\mathrm{Ca}^{2+}$ transport at the cell membrane level should be evaluated (Roden and Kupershmidt, 1999).
Considering that it might be conceivable, RyRs expression differences might be associated with the potential skeletal muscle PSE characteristics in the affected birds, the objective of this study was to determine the differences at the expression levels of the ryanodine receptor genes, $\alpha-r y r$ and $\beta$-ryr by real time PCR in PSE and non-PSE Pectoralis major $\mathrm{m}$. from two phenotypically distinct chicken lines i.e. broiler and layer line.

\section{MATERIALS AND METHODS}

\section{Experimental animals and sample collection}

One hundred and two chickens (Gallus gallus) from a broiler male line (TT) and 102 from a layer line (CC), both developed by Embrapa Swine and Poultry Research Center, were used in this study. Chickens were reared as broilers and were slaughtered at 45 days of age with average weight of $450.3 \mathrm{~g}$ (CC) and $2.298 \mathrm{~g}$ (TT). Birds were slaughtered manually under laboratory conditions by cutting the carotid artery and jugular vein without previous electrical stunning. Just after bleeding, muscle samples $\left(0.5 \times 2.0 \times 1.0 \mathrm{~cm}^{3}\right)$ were collected and stored in micro tubes $(1.5 \mathrm{~mL})$, rapidly frozen in liquid nitrogen and stored at $70^{\circ} \mathrm{C}$. Pectoralis major m. samples were deboned and skinned immediately after slaughter and stored at $4^{\circ} \mathrm{C}$ for $24 \mathrm{~h}$.

\section{Color Measurement}

Minolta CR10 colorimeter (Minolta Corp., Ramsey, NJ) was used to evaluate the color, $\mathrm{L}^{*}$ (lightness), $\mathrm{a}^{*}$ (redness) and $\mathrm{b}^{*}$ (yellowness) (CIELAB color system) on the posterior surface of the intact skinless breast muscles at $24 \mathrm{~h}$ post mortem. The $\mathrm{L}^{*}$ values were measured at three different sites in the same sample.

\section{pH Measurement}

$\mathrm{pH}$ was measured by inserting electrodes into the breast muscle using a portable digital $\mathrm{pH}$ meter with 0.01 units resolution (PH-720, Instrutherm). Analyses were performed in duplicate at $24 \mathrm{~h}$ post mortem (Olivo et al., 2001).

\section{Samples classification}

Birds fillets were selected based on mean $\mathrm{L}^{*}$ values higher than 53.0 for PSE and $\mathrm{pH}_{24 \mathrm{~h}}<5.8$ and 44.0 to 53.0 for the non-PSE group (Soares et al., 2003). 
Total RNA extraction and cDNA synthesis

Total RNA was extracted from Pectoralis major $m$. based on the method developed by Chomczynski and Sacchi (1987) and was reverse transcribed into cDNA using Moloney murine leukemia virus transcription (M-MLV) (Invitrogen). Briefly, the reverse transcription reaction was performed in a $25 \mu \mathrm{L}$ volume. An RNA-primer mix [ $2 \mu \mathrm{L}$ of oligo (dT) primer, $2.5 \mu \mathrm{g}$ of total RNA $(5 \mu \mathrm{L})]$ was heated at $80^{\circ} \mathrm{C}$ for $3 \mathrm{~min}$. This mixture was immediately incubated on ice and $18 \mu \mathrm{L}$ of reaction mix [6 $\mu \mathrm{L}$ of 5 X FirstStrand Buffer (250 mM Tris-HCl, pH 8.3, $375 \mathrm{mM}$ $\mathrm{KCl}, 15 \mathrm{mM} \mathrm{MgCl}_{2}$, and $50 \mathrm{mM}$ dithiothreitol), 4 $\mu \mathrm{L}$ of $2.5 \mathrm{mM}$ dNTP mix (dATP, dCTP, dGTP, and dTTP), $2 \mu \mathrm{L}$ of M-MLV (200 U/ $\mu \mathrm{L}), 4 \mu \mathrm{L}$ of nuclease free-water and $2 \mu \mathrm{L}$ of dithiothreitol (DTT)] were added. This complete reaction mixture was incubated at $37^{\circ} \mathrm{C}$ for $60 \mathrm{~min}$ and heated at $65^{\circ} \mathrm{C}$ for $10 \mathrm{~min}$ for its inactivation.

\section{Relative quantification by Real Time PCR}

Four PSE meat and four non-PSE meat samples were selected from each line for real time quantitative PCR (RT-PCR) analysis. Two pools of cDNAs from non-PSE meat from each line were prepared and used as control samples. $\beta$-actin gene expression was used as an internal standard. RT-PCR analyses were performed using Platinum $^{\circledR}$ SYBR $^{\circledR}$ Green qPCR Superix UDG (Invitrogen Life Technologies) kits, according to the manufacturer protocol. The PCR reaction consisted of $2 \mu \mathrm{L}$ of RT reaction diluted with $8 \mu \mathrm{L}$ of nuclease free water, $12.5 \mu \mathrm{L}$ of SYBR Green, $0.5 \mu \mathrm{L}$ of ROX dye, and $1 \mu \mathrm{L}$ each of the forward and reverse primers. Reaction components were assembled in multiple low-profile plates and sealed with Microseal B Adhesive Seals. The standard curves to check $\alpha$-RyR, $\beta$-RyR and $\beta$ actin primer amplification efficiency were performed using dilution series of $10^{-1}, 10^{-2}$ and $10^{-3}$. Forward and reverse primer sequences used for amplification of $\beta$-RyR (GI:46048743) and $\beta$ actin (GI:45382926) were designed using the Primer Express Program (Applied Biosystems, Foster, CA), and are listed, respectively, as follow: 5'-CTGGCCAGGAGTCATTTGTGT-3', 5' TGGGAAGAAATCCCAGCATCT-3' (product size: 59 base pairs (bp)) and 5'-TTCTTTTGGCG CTTGACTCA-3', 5'-GCGTTCGCTCCAACA TGTT-3' (product size: 88 bp). Forward (5'GGCGGGGCTCTACGGGAGCTT-3’) and reverse (5'-ACGTTCAGCCGGTCGATGCA
GTT-3') primers for $\alpha$-RyR were similar to those described by Maak et al. (2005) for turkeys, and resulted in a PCR product of $210 \mathrm{bp}$. The primers specificity was confirmed by DNA sequence analysis of the amplified PCR product. The real time PCR amplification was performed in a 7300 Real Time System thermocycler (Applied Biosystems, Foster, Ca). The final PCR products were analyzed on a $1.0 \%$ ethidium bromidestained agarose gel to check for amplification specificity (Liu et al. 2005). The cycling program consisted of a denaturation step $\left(95^{\circ} \mathrm{C}\right.$ for $\left.10 \mathrm{~min}\right)$ followed by amplification and quantification steps (45 cycles of $95^{\circ} \mathrm{C}$ for $2 \mathrm{~min}, 55^{\circ} \mathrm{C}$ for $30 \mathrm{~s} ; 72^{\circ} \mathrm{C}$ for $30 \mathrm{~s}$ ), with a single fluorescence measurement at the end of each cycle. The melting curve program was set at $95^{\circ} \mathrm{C}$ for $15 \mathrm{~s}, 60^{\circ} \mathrm{C}$ for $30 \mathrm{~s}$ and $95^{\circ} \mathrm{C}$ for $15 \mathrm{~s}$.

\section{Statistical analysis}

Data were analyzed by examining differences between the ultimate $\mathrm{pH}$ and color $\left(\mathrm{L}^{*}{ }_{24 \mathrm{~h}}\right)$ by a ttest using the STATISTICA Program version 6.0 (STATSOFT, 1995). Differences were considered significant at $\mathrm{p}<0.05$. Gene expression data (RQ) were analyzed in a randomized complete block design (RCBD), with 4 blocks (replications), described in the following model: $Y_{i j}=$ $\mu+C_{i}+B_{j}+\varepsilon_{i j}$, where $Y_{i j}$ is the observed RQ value from the meat sample (PSE/TT or non PSE/TT or PSE/CC or non-PSE/CC) in block $j ; \mu$ is the general mean; $C_{i}$ is the meat sample (where $i=1$ to 4 ); $B_{j}$ is the block effect (where $\mathrm{j}=1$ to 4 ); and $\varepsilon_{\mathrm{ij}}$ is the random error associated with the $\mathrm{Y}_{\mathrm{ij}}$ experimental unit. The data were analyzed using the SAS statistical package (SAS Institute, 1989). All assumptions required by the analysis of variance were verified. The error normality, according to the experimental model design, was evaluated by the Shapiro-Wilk test (1965), the homogeneity of variance by the Burr-Foster test (1972) and the non-additivity of the model by Tukey's method (1949). The coefficients of skewness and kurtosis were also checked. Differences were considered significant at a level of $p<0.05$. Differences between the means of treatments were evaluated by Tukey's test.

\section{RESULTS AND DISCUSSION}

In the present work, a hypothesis was adopted that the broiler chicken line (TT) would present higher 
incidence of PSE meat than the layer chicken line (CC). This could be related to differences in the gene expression levels on the calcium channel proteins $(\alpha-R y R$ and $\beta-R y R)$ in breast muscle. Meat was classified as PSE when presented values of $\mathrm{L}^{*}{ }_{24 \mathrm{~h}}>53.0$ and $\mathrm{pH}_{24 \mathrm{~h}}<5.8$ (Olivo et al. 2001, Guarnieri et al. 2004, Barbut, 1997). Ten cases of PSE meat $(9.8 \%)$ in the TT line and 4 cases $(3.9 \%)$ in the CC line were found. The higher number in the incidence of meat with poor quality in TT line was in agreement with Le Bihan-Duval et al. (1999) and Berri et al. (2001) studies, which reported that genetic selection for increased body weight and breast meat yield was related to the increase in the PSE cases.

The $\mathrm{pH}_{24 \mathrm{~h}}$ and color $\left(\mathrm{L}^{*}, \mathrm{a}^{*}, \mathrm{~b}^{*}\right)$ values of chicken breast meat are shown in Table 1. The ultimate mean $\mathrm{pH}$ values of both chicken lines studied were: 5.92 (TT) and 6.09 (CC), similar to those found by Barbut (1997) and Olivo et. al, (2001), Soares et al., (2003), and Guarnieri et al. (2004) with values ranging from 5.56 to 6.42 . The broiler line (TT) presented lower $\mathrm{pH}$ values than the layer line (CC). In the present study, TT breast (Pectoralis major $m$.) muscle had higher values $(\mathrm{p}<0.05)$ of luminosity $\left(\mathrm{L}^{*}\right)$ than $\mathrm{CC}$. The lower $(p<0.05) a^{*}$ values found in TT line $(5.25 \pm 0.12)$ in relation to the $\mathrm{CC}$ line $(9.94 \pm 0.24)$ could be attributed in part to a decrease in the concentration of muscle pigments observed in muscle of selected lines (Berri et al. , 2001). Meat redness (a*) and yellowness $\left(b^{*}\right)$ were significantly reduced in the broiler line than its non-selected control line (Le Bihan-Duval, 1999).

Table 1 - Meat quality attributes of breast fillets from two chicken lines.

\begin{tabular}{lcc}
\hline Attribute & Broiler male line $(\text { TT })^{\mathbf{1}}$ & ${\text { Layer line }(\mathbf{C C})^{\mathbf{1}}}^{\mathbf{p H}}$ \\
$\mathrm{pH}{ }_{24 \mathrm{~h}}$ & $5.92^{\mathrm{b}} \pm 0.02$ & $6.09^{\mathrm{a}} \pm 0.01$ \\
$\mathrm{C}$ olor & $51.85^{\mathrm{a}} \pm 0.25$ & \\
$\mathrm{~L}^{*}$ & $5.25^{\mathrm{b}} \pm 0.12$ & $50.81^{\mathrm{b}} \pm 0.28$ \\
$\mathrm{a}^{*}$ & $11.65^{\mathrm{b}} \pm 0.14$ & $9.94^{\mathrm{a}} \pm 0.24$ \\
$\mathrm{~b}^{*}$ & & $15.95^{\mathrm{a}} \pm 0.21$ \\
\hline
\end{tabular}

$\overline{\mathrm{a}, \mathrm{b}}$ Means within row with no common superscript differ significantly by $\mathrm{t}$ test $(\mathrm{p} \leq 0.05)$.

${ }^{1} \mathrm{n}=102$ birds/ line.

In this study, a total of four samples PSE and four samples of non-PSE from each line were selected, following the color and $\mathrm{pH}$ criteria described before. The average $\mathrm{L}^{*}{ }_{24 \mathrm{~h}}$ values in PSE samples from TT and CC lines, selected for gene expression analysis, were $56.57( \pm 0.78)$ and 55.4 $( \pm 0.79)$, respectively. In non-PSE samples, results of $50.45( \pm 0.55)$ and $49.95( \pm 0.78)$, respectively, were observed. The $\mathrm{pH}_{24 \mathrm{~h}}$ values of TT and CC samples (5.65 \pm 0.06 and $5.73 \pm 0.02$, respectively), were lower $(\mathrm{p}<0.05)$ than the normal samples from both lines studied, which presented values of 5.99 $( \pm 0.03)$ and $6.14( \pm 0.05)$, respectively. The $\mathrm{L}^{*}{ }_{24 \mathrm{~h}}$ and $\mathrm{pH}_{24 \mathrm{~h}}$ values of PSE and Normal samples from broiler and layer lines used in this analysis presented negative correlation $(\mathrm{p}<0.001)$ as shown in Figure 1. Other studies also reported that lower values of $\mathrm{pH}$ in fillets were related to the higher L* values (Barbut, 1997, Soares et al., 2003).

The real-time PCR technique was used to investigate the expression of genes $\alpha$-ryr and $\beta$-ryr in muscle tissue (Pectoralis major m.). Primer amplification efficiency was tested by efficiency curves for $\alpha-R y R, \beta-R y R$ and $\beta$-actin, and showed linear regression coefficients and slopes of 0.9940 and $-4.2335 ; 0.9921$ and $-3.6482 ; 0.9980$ and 2.8053 , respectively.

Gene expression analyses (RQ) data are presented in Table 2. The RQ values for the $\beta$-RyR gene in PSE birds were lower $(p<0.05)$ than in non-PSE samples. In relation to $\alpha-R y R$ gene expression, there was no difference $(p>0.05)$, regardless of chicken lines considered. Maak et al. (2005) also did not find significant differences in $\alpha$-RYR receptor gene expression in skeletal muscles of turkeys with poor meat quality. The lower $\beta$-RyR mRNA levels observed in PSE muscles in this study could be considered as indicative of the lower number of available $\beta$-RyRs in the periphery of the SR, thus leading to a non-balanced increase in the well-known RyR1:RyR3 ratio (1:1) found in birds and amphibians (Sutko and Airey, 1996). 


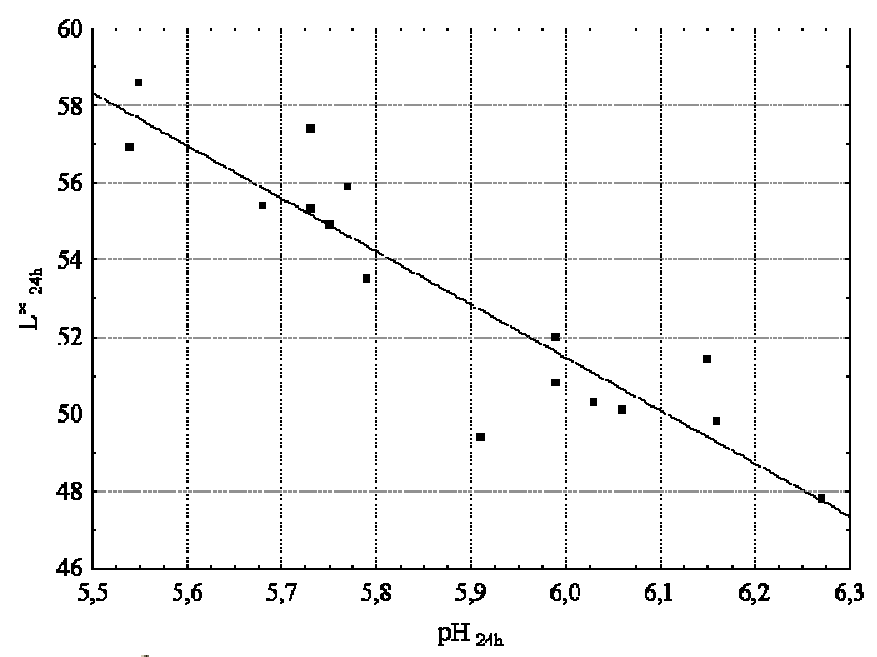

Figure 1 - Relationship between $\mathrm{pH}$ and $\mathrm{L}^{*}$ values of PSE and normal breast fillets samples, at 24 $\mathrm{h}$ post mortem, from two distinctly different chicken lines selected for the gene expression analysis $(\mathrm{p}<0.001, \mathrm{r}=-0.9172)$.

In the interpretation of these results, it is necessary to take into consideration the transcription mechanism governing the conversion of genomic information to its translation into an active protein. It is by transcription that all cells RNAs are synthesized. The mRNAs are used to transfer genetic information from DNA to protein synthesis, and other types of RNA have structural and catalytic functions. RT-PCR gene expression analyses use mRNA from different samples, aiming to identify amount differences among samples that could be related to the occurrence of PSE meat. However, very little is known about the control of ion channel gene transcription, but the process certainly begins with regulatory factors guiding chromatin unfolding. Then, RNA polymerase enzymes recognize promoters, interacting with enhancer sequences. Once transcribed a long series of RNA modifications can occur before it can be used in translation (Roden and Kupershmidt, 1999).

Mutations in the gene sequence of the RyR1, could result in changes in the sensitivity of the calcium channel to many ligands that act in the calcium release (Murayama and Ogawa, 2004). Mickelson et al. (1994) described that swine homozygous (nn) prone to Malignat Hyperthemia development, presented lower content of junctional membranes in the Sarcoplasm Reticulum (SR), with a correspondent reduction in the components of the calcium channel, including DHPR and RyR subunits. This could be a tool for the cell adaptation to the excessive release of calcium ions by the RyR mutant.

Table 2 - Real time PCR analysis of $\alpha$-ryr and $\beta$-ryr genes in pale, soft, and exudative chicken meat (Pectoralis major, m.) from two distinctly chicken lines.

\begin{tabular}{ccccc}
\hline & \multicolumn{2}{c}{ Broiler male line (TT) $)^{\mathbf{1}}$} & \multicolumn{2}{c}{ Layer line (CC) } \\
\hline Gene & PSE & Normal (Control) & PSE & Normal (Control) \\
\hline$\alpha-R y R$ & $1.3374^{\mathrm{a}} \pm 0.1526$ & $1.0^{\mathrm{a}} \pm 0.0$ & $0.9400^{\mathrm{a}} \pm 0.1608$ & $1.0^{\mathrm{a}} \pm 0.0$ \\
$\beta-R y R$ & $0.8385^{\mathrm{b}} \pm 0.0560$ & $1.0^{\mathrm{a}} \pm 0.0$ & $0.7936^{\mathrm{b}} \pm 0.0680$ & $1.0^{\mathrm{a}} \pm 0.0$ \\
\hline
\end{tabular}

${ }_{\mathrm{a}, \mathrm{b}}$ Means within row with no common superscript differ significantly by Tukey's test ( $\left.\mathrm{p} \leq 0.05\right)$.

${ }^{1} \mathrm{n}=8$ birds/ line. 
It was expected that together with the arrival of electric impulses in the transverse tubules, $\alpha$-RyRs would be activated and $\mathrm{Ca}^{2+}$ ions released from the triads to cytosol. After that, attachment of these ions to the available $\beta$-RyRs in the SR might possibly result in higher concentrations of calcium in the intracellular environment in animals prone to the development of PSE meat as $\beta$-RyRs were much more reactive to the presence of this ion and furthermore, and they were not deactivated at milimolar concentrations (Shirokova et al., 1996).

Finally, these ion channels have longer channel openings and once activated, show an increase in the frequency of these openings (Percival et al., 1994). Therefore, these small amounts of calcium release could prepare the muscle fiber to be quickly activated by a subsequent stimulus (O'Brien et al. , 1995). The increase of $\mathrm{Ca}^{2+}$ in the cytosol could, in turn, increase the availability of the ion concentration and in sequence to chemically associate to troponin $\mathrm{C}$ resulting in muscle contraction and ultimately to the PSE meat formation.

\section{CONCLUSIONS}

Results showed that there was no difference in $\alpha-r y r$ expression for both broiler and layer chicken lines, with and without PSE meat. However, the relative quantification lower mean values for the $\beta$-ryr in PSE meat in both lines suggested that it could be one of the factors involved in the PSE meat syndrome development.

\section{ACKNOWLEDGEMENTS}

This work was partially funded by $\mathrm{CNPq}(\mathrm{CNPq} \#$ 471665/04-5), Fundação Araucária (Protocol \# 5230), and PRODETAB/EMBRAPA (Project/Sub. 038-01/01). We also acknowledge Bunka Research Support Funding. Thanks also go to the CAPES Foundation for both a graduate scholarship and for the sandwich grants awarded to SHIO for training at Michigan State University. ALN, EII and MS are CNPq Research Fellows.

\section{RESUMO}

As proteínas $\alpha$-RyR e $\beta$-RyR apresentam papéis distintos no mecanismo de excitação-contração com diferenças em seus mecanismos de ativação e respostas a ligantes. O RNA total de filé de peito (Pectoralis major $m$ ) com PSE $\left(\mathrm{L}^{*}{ }_{24 \mathrm{~h}}>53,0 ; \mathrm{pH} 5,8\right)$ e não-PSE $\left(44 \leq \mathrm{L}^{*}{ }_{24 \mathrm{~h}} \geq 53\right)$ de duas linhagens distintas, de corte e de postura, foram utilizadas para estudar a expressão gênica dos genes $\alpha$-ryr e $\beta$ ryr por PCR-em-tempo-real. Os valores médios de expressão gênicas relativas (RQ) foram inferiores $(\mathrm{p}<0,05)$ para $\beta$-ryr em frangos PSE das duas linhagens quando comparadas aos frangos não-PSE. Por outro lado, não houve diferenças $(p>0,05)$ na expressão do $\alpha-r y r$, independentemente da linhagem estudada. Os resultados de RQ para $\beta$-ryr indicaram nas amostras PSE, uma alteração na proporção (1:1) de $\alpha$-RyR/ $\beta$-RyR comumente encontrada em músculos de aves. Estes resultados originam a primeira evidência da ocorrência de carnes PSE como resultado de uma disponibilidade acentuada de $\mathrm{Ca}^{2+}$ no citosol pela expressão diferenciada de proteínas receptoras de rianodina.

\section{REFERENCES}

Barbut, S. (1997), Problem of pale, soft, exudative meat in broiler chickens. Br. Poultry Sci., 38, 355-358

Berri, C., Wacrenier, N., Millet, N. and Le Bihan-Duval, E. (2001), Effect of selection for improved body composition on muscle and meat characteristics of broilers from experimental and commercial lines. Poult. Sci., 80, 833-838

Burr, I. W. and Foster, L. A. (1972), A test for equality of variances. Mimeo series $\mathrm{n}^{\mathrm{o}}$ 282. University of Purdue, West Lafayette, 26 p

Chomcznski, P. and Sacchi, N. (1987), Single step method method of RNA isolation by acid guanidinium thiocyanate-phenol-chloroform extraction. Anal. Biochemistry, 162, 156-159

Dransfield, E. and Sosnicki, A. A. (1999), Relationship between muscle growth and poultry meat quality. Poult. Sci., 78, 743-746

Fujii, J., Otsu, K., Zorzato, F., Leon, S., Khanna, V. K., Weiler, J. E., O'Brien, P. J. and Maclennan, D. H. (1991), Identification of mutation in porcine ryanodine receptor associated with malignant hyperthermia. Science, 253, 448-451 
Guarnieri, P. D., Soares, A. L., Olivo, R., Schneider, J. P.; Macedo, R. M.; Ida, E. I. and Shimokomaki, M. (2004), Preslaughter handling with water shower spray inhibits PSE (Pale, Soft, Exudative) broiler breast meat in a commercial plant. Biochemical and Ultrastructural observations. J. Food Biochemistry, 28, 269-277

Jurkat-Rott, K., McCarthy, T., Lehmannn-Hornm, F. (2000), Genetics and pathogenesis of malignant hyperthermia. Muscle Nerve, 23, 4-27

Lara, J. A. F., Nepomuceno, A. L., Ledur, M. C., Ida, E. I. and Shimokomaki, M. (2003), Chicken PSE (Pale, Soft, Exudative) meat. Mutations in the ryanodine receptor gene. Proceedings of International Congress of Meat Science and Technology. 49, 79-80

Le Bihan-Duval, E., Millet, N. and Remingnon, H. (1999), Broiler meat quality: effect of selection for increased carcass quality and estimates of genetic parameters. Poult. Sci., 78, 822-826

Lin, C. J. and Barbosa, A. S. (2002), Techniques for gene transcription regulation analysis and their application in molecular endocrinology. Arquivos Brasileiros de Endocrinologia and Metabologia, 46, 330-340

Liu, C., McFarland, D. C. and Velleman, S. G. (2005), Effect of genetic selection on myoD and myogenin expression in turkeys with different growth rates. Poult. Sci., 84, 376-384

Maak, S., Wicke, M. and Swalve, H. H. (2005), Analysis of gene expression in specific muscles of swine and turkey. Arch. Tierz. Dummerstorf, 48, Special Issue, 135-140

McLennan, D. H.; Phillips, M. S. (1992), Malignant hyperthermia. Science, 256, 789-794

Mickelson, J. R.; Ervasti, J. M.; Litterer, L. A.; Campbell, K. P. and Louis, C. F. (1994), Skeletal muscle junctional membrane protein content in pigs with different ryanodine receptor genotypes. The American Journal of Physiology, Bethesda, 267, C282-C292

Murayama, T. and Ogawa, Y. (2004), RyR1 exhibits lower gain of CICR activity than RyR3 in the SR: evidence for selective stabilization of RyR1 channel. American Journal Physiology, 287, C36-C45

O'Brien, J.; Valdivia, H. H. and Block, B. A. (1995), Physiological differences between the alpha and beta ryanodine receptors of fish skeletal muscle. Biophysical J., 68, 471-482
Olivo, R., Soares, A. L., Ida, E. I. and Shimokomaki, M (2001), Dietary Vitamin E inhibits poultry PSE and improves meat function properties. J. Food Biochemistry, 25, 271-283

Owens, C. M., Hirschler, E. M., McKee, S. R., MartinezDawson, R. and Sams, A. R. (2000), The characterization and incidence of pale, soft, exudative turkey meatin a commercial plant. Poult. Sci., 79, 553558

Percival, A. L., Williams, A. J., Kenyon, J. L., Grinsell, M. M. and Sutko, J. L. (1994), Chicken skeletal muscle ryanodine receptor isoforms: ion channel properties. Biophysical Journal, 67, 1834-1850

Roden, D. M. and Kupershmidt, S. (1999). From genes to channels: normal mechanisms. Cardiovascular Research, 42, 318-326

SAS Institute Inc., Cary, NC, USA. (1992), Shapiro, S. S. and Wilk, M. B. (1965), An analysis of variance test for normality. Biometrika, 52, 591-611

Shirokova, N. García, J. Pizarro, G. and Ríos, E. (1996), $\mathrm{Ca}^{2+}$ release from the sarcoplasmic reticulum compared in amphibian and mammalian skeletal muscle. J. Gen. Physiol., 107, 1-18

Soares, A., L., Ida, E. I., Miyamoto, S., Blazquez, F. J. H., Olivo, R.,Pinheiro, J. W. and Shimokomaki, M. (2003), Phospholipase $A_{2}$ activity in poultry PSE, Pale, Soft, Exudative. J. Food Biochemistry, 27, 309-319

Statistica for Windows 5.0. Computer program manual. Tulsa, OK: StatSoft, Inc. (1995), Strasburg, G. M. and Chiang, W. (2003), Genetic Basis for Pale, Soft and Exudative Turkey meat. Reciprocal Meat Conference, 56, 17- 22

Sutko, J. L. and Airey, J. A. (1996), Ryanodine receptor $\mathrm{Ca}^{2+}$ release channels: does diversity in form equal diversity in function. Physiological Review, 76, $1027-$ 1071

Tukey, J. W. (1949), One degree of freedom for nonadditivity. Biometrics, 5, 232-242

Werner, C., Opalka, J. R. and Gellerich, F. N. (2005), The influence of mitochondrial function on meat quality in turkey and swine. Arch. Tierz.Dummenstorf, 48, 106-111 